\title{
Surgery and risk for multiple sclerosis: a systematic review and meta-analysis of case-control studies
}

\author{
Carole Lunny, Jennifer A Knopp-Sihota and Shawn N Fraser ${ }^{*}$
}

\begin{abstract}
Background: Although the precise etiology of multiple sclerosis is largely unknown, there is some speculation that a prior history of surgery may be associated with the subsequent risk for developing the disease. Therefore, we aimed to examine surgery as a risk factor for the diagnosis of multiple sclerosis.

Methods: We searched for observational studies that evaluated the risk for developing multiple sclerosis after surgery that occurred in childhood ( $\leq 20$ years of age) or "premorbid" (> 20 years of age). We specifically included surgeries classified as: tonsillectomy, appendectomy, adenoidectomy, or "surgery". We performed a systematic review and meta-analyses and calculated odds ratios (OR) and their $95 \%$ confidence intervals (Cls) using a random effects model.

Results: We identified 33 case-control studies, involving 27,373 multiple sclerosis cases and 211,756 controls. There was a statistically significant association between tonsillectomy $\left(\mathrm{OR}=1.32,95 \% \mathrm{Cl} 1.08-1.61 ; 12\right.$ studies, $\left.\mathrm{I}^{2}=44 \%\right)$ and appendectomy $\left(\mathrm{OR}=1.16,95 \% \mathrm{Cl} 1.01-1.34 ; 7\right.$ studies, $\left.\mathrm{I}^{2}=0 \%\right)$ in individual's $\leq 20$ years of age and the subsequent risk for developing multiple sclerosis. There was no statistically significant association between risk for multiple sclerosis and tonsillectomy occurring after age $20\left(\mathrm{OR}=1.20,95 \% \mathrm{Cl} 0.94-1.53 ; 9\right.$ studies, $\left.\mathrm{I}^{2}=32 \%\right)$, in those with appendectomy at $>20$ years $\left(\mathrm{OR}=1.26,95 \% \mathrm{Cl} 0.92-1.72 ; 5\right.$ studies, $\left.\mathrm{I}^{2}=46 \%\right)$, and in those with adenoidectomy at $\leq 20$ years of age $\left(\mathrm{OR}=1.06,95 \% \mathrm{Cl} 0.68-1.68 ; 3\right.$ studies, $\left.\mathrm{I}^{2}=35 \%\right)$. The combined $\mathrm{OR}$ of 15 studies $(\mathrm{N}=2,380)$ looking at "surgery" before multiple sclerosis diagnosis was not statistically significant ( $\mathrm{OR}=1.19$, $\left.95 \% \mathrm{Cl} 0.83-1.70 ;\left.\right|^{2}=71 \%\right)$.

Conclusions: We found a small but statistically significant and clinically important increased risk for developing multiple sclerosis, in those with tonsillectomy and appendectomy at $\leq 20$ years of age. There was no convincing evidence to support the association of other surgeries and the risk for multiple sclerosis. Well-designed prospective etiological studies, pertaining to the risk for developing multiple sclerosis, ought to be conducted and should include the examination of various surgeries as risk factors.
\end{abstract}

Keywords: Adenoidectomy, Appendectomy, Multiple sclerosis, Observational studies, Risk, Surgery, Systematic review, Tonsillectomy

\footnotetext{
* Correspondence: shawn.fraser@athabascau.ca

Centre for Nursing and Health Studies, Faculty of Health Disciplines,

Athabasca University, 1 University Drive Athabasca, Alberta T9S 3A3, Canada
} 


\section{Background}

Multiple sclerosis (MS) is a complex immune-mediated inflammatory disease of the central nervous system affecting an estimated 2 million people worldwide [1]. MS, one of the most common non-traumatic neurological disorders in younger adults, affects more females (than males) with a population prevalence of approximately $0.1 \%$ in North America [1]. The epidemiological and clinical importance of MS lies in the significant disability and morbidity attributed to the disease. Not only is the condition relatively common, it is costly with an estimated economic burden exceeding \$6 billion annually in the United States alone [2].

\section{Description of the condition}

The first symptoms or signs of MS, diagnosed by a physician, are referred to as the clinical onset of the disease. As there are limited (and consistent) clinical, laboratory, and imaging findings in MS, diagnostic classifications are generally reduced to "definite MS" and "possible MS". Several established diagnostic standards have been used over the years to assist physicians in the diagnosis of MS; these include criterion such as the Poser criteria [3] and most recently the McDonald criteria [4].

Although the precise etiology of MS is largely unknown, epidemiological studies point at an important role in both genetic and environmental factors that seem to act synergistically increasing an individual's risk of developing the disease. Specifically, risks such as genetic factors (the presence of HLA-DRB1*15 alleles), infectious causes including Epstein-Barr virus (EBV), vitamin $\mathrm{D}$ insufficiency, exposure to cigarette smoke, and a more northern geographic residence (latitude) have all been well documented in the literature [5-9]. There is some speculation that other factors, including a history of tonsillectomy, appendectomy, or other surgery may also be associated with the risk of developing MS [10].

\section{Relevance of systematic review and meta-analysis}

Although there have been studies examining prior surgery as a risk factor for MS, these studies have generally been smaller-scale observational studies of varied methodological quality in which a wide range of both positive and negative results have been reported. Therefore, we conducted a formal Cochrane style systematic review and meta-analysis of observational studies to examine the association between tonsillectomy, appendectomy, adenoidectomy, and other "surgery" and the risk of developing MS. We are not aware of another similar published meta-analysis on this topic; therefore, a systematic review (SR) including meta-analysis is timely.

\section{Methods}

We followed the procedures for conducting systematic reviews and meta-analysis as outlined by the Cochrane
Collaboration [11] and the reporting guidelines of the Meta-Analysis of Observational Studies in Epidemiology (MOOSE) [12].

\section{Search strategy}

Studies were identified by several methods. First, we searched for completed reviews in the Database of Abstracts of Reviews of Effects (DARE), Evidence for Policy and Practice Information (EPPI) Centre, the HealthEvidence.ca website, and the Cochrane Database of Systematic Reviews (CDSR). We searched for individual studies in the MEDLINE, EMBASE, SCIRUS, Web of Science, PubMed, and the LILACS (Latin American and Caribbean Computer Library Center) databases. The Google Web search engine (www.google.com) and Google Scholar (scholar.google.com) were used to locate articles that may not have been included in the above databases. Grey literature was searched using 'OpenSIGLE, 'NTIS', 'Health Management Information,' 'British National Bibliography for Report Literature,' Proquest Dissertations and Theses - Full Text, Dissertation Abstracts, CINHAL, and CyberTesis.

We used the following text words and Medical Subject Headings: (a) multiple sclerosis OR demyelinating disease, and (b) surgery; surgical intervention; operations; medical history; hospitalisation; tonsillectomy; anaesthetic; appendectomy; adenoidectomy; risk factor; etiologic factor; severe; minor; association; causation; casecontrol; cohort. In addition, reference lists of all relevant articles were examined for further pertinent studies; and conference proceedings were sought from various web sites and organizations. Forward citation searches of included studies and relevant literature reviews were also done. Primary authors and experts in the field were contacted to identify additional published, unpublished, or 'in-progress' studies. The search was not limited by publication date, language, or publication status. All databases were last accessed in August 2012.

\section{Inclusion criteria}

We planned to include a broad range of observational studies: cohort, case-control, and cross sectional designs. As there were few primary studies, we also planned to include retrospective studies utilizing secondary data from healthcare databases. To be eligible for inclusion, studies needed to include patients with physician diagnosed MS (preferably by using diagnostic criteria for a definite diagnosis of MS) and report original data. Studies were excluded if there was no control group.

The primary outcome of interest was the development of MS following a past history of tonsillectomy, appendectomy, adenoidectomy, or other surgery. If the authors did not specify the type of surgery, we included these 
studies and classified them as "other surgery". Surgeries were defined according to their classification in each individual study. Further, due to the estimated mean latency period and the critical age at puberty, these categories and sub-categories were divided by age at the time of surgery: (1) age $\leq 20$ years, and (2) $>20$ years.

\section{Data collection and analysis Selection of studies}

One of the study investigators (CL) performed the initial search of all databases to identify potentially relevant citations. Where it was not possible to accept or reject the study, the full text of the citation was obtained for further evaluation. Following the screening of titles and abstracts, the full texts of potential articles were retrieved (and translated into English where required) and assessed independently by two of the study investigators (CL, JKS). If any differences in opinion occurred, they were resolved by consensus with a third reviewer.

\section{Data extraction and management}

Data were independently extracted by one unmasked reviewer (CL) using a standardized electronic data collection form and were then checked by a second reviewer (JKS) for accuracy. When raw data were not provided, the data were extracted from figures; where necessary, we attempted to seek additional information from first or corresponding authors of the included studies via electronic mail. The following information was obtained for each study (where possible): source, eligibility, methods, participant demographics, MS diagnostic information, confounding variables adjusted for, outcome exposures, and results.

\section{Quality assessment: Risk of bias in included studies}

After identification of articles meeting the inclusion criteria, two review authors (CL, JKS) independently assessed the methodological quality of studies according to the criteria of the Newcastle-Ottawa Quality Assessment Scale (NOS) as recommended by the Cochrane Collaboration for assessing the quality of nonrandomized studies [13]. The NOS is based on a cumulative score in each of three broad categories: selection of study groups, comparability of their cases and controls, and their ascertainment of the outcome / exposure on cases and controls. If a study fulfils the criteria for an item, a score of 1 point is allocated, with the exception of comparability which can score up to 2 points, resulting in a maximum score of 9 . Similar to other reviews, we considered studies that received a score of $\geq 6$ on the NOS criteria to be of high quality. We specifically classified studies as high risk of bias (1-3 points), medium risk of bias (4-5 points), or low risk of bias (6-9 points). In the case of disagreement between reviewers, differences were to be resolved by discussion until consensus was achieved.

\section{Dealing with missing data}

As missing data (statistics) were evident in many of the included studies, we attempted to contact 13 separate investigators at least twice. Six authors replied, and two provided the requested data; therefore, available data were extracted from published reports, and missing data were imputed. For those studies reporting "no significance", with no additional statistical data, we assumed an odds ratio (OR) of 1.0 and estimated the confidence intervals (CIs) based on the number of reported MS cases [14]. Sensitivity analyses were performed to check the effect of imputation.

\section{Assessment of heterogeneity and reporting bias}

Heterogeneity between studies was examined visually using the $\mathrm{I}^{2}$ statistic. Deeks and colleagues (for the Cochrane Collaboration) [15] suggest the following as a rough guide for interpreting the $\mathrm{I}^{2}$ statistic:

- $0 \%$ to $40 \%$ : might not be important;

- $30 \%$ to $60 \%$ : may represent moderate heterogeneity;

- $50 \%$ to $90 \%$ : may represent substantial heterogeneity;

- $75 \%$ to $100 \%$ : considerable heterogeneity.

Possible sources of heterogeneity were assessed by sensitivity analyses and described qualitatively in Table 1 (Characteristics of included studies).

Stratified meta-regression, based on sub-groups including 10 or more studies, was performed to further examine heterogeneity. A priori, we planned to explore the following population-level continuous variables (geographic latitude, female-to-male MS case ratio, mean age of MS onset), and study-level dichotomous variables (language [English vs. non-English]), publication type [published vs. unpublished], number of covariates adjusted for [ $\leq 2$ vs. $>2$ ], total sample size [ $\leq 100$ vs. $>$ $100]$, and sample size of MS cases [ 100 vs. > 100]. Odds ratios $(\beta)$ and $95 \%$ CIs were calculated using the study level log OR and the standard error (SE) of the estimate by constructing univariate random effects (RE) meta-regression models in STATA 12 using the megareg command. A plot of ORs was done against NOS scores to determine if there was a linear relationship between the methodological quality of the studies and their results [16]. We planned to explore publication bias and other potential reporting biases, in those pooled comparisons with 10 or more studies, using funnel plots. We used the graphical approach described by Peters et al. for assessing dichotomous outcomes with effects measured as odds ratios [17]. 
Table 1 Characteristics of included studies

\begin{tabular}{|c|c|c|c|c|c|c|c|c|c|c|c|c|c|}
\hline $\begin{array}{l}\text { Author (year) } \\
\text { Country }\end{array}$ & $\begin{array}{l}\text { MS } \\
\text { (n) }\end{array}$ & $\begin{array}{l}\text { Control } \\
\text { group } \\
\text { (n) }\end{array}$ & $\begin{array}{l}\mathrm{F}: \mathrm{M} \\
\text { cases }\end{array}$ & $\begin{array}{l}\text { Mean } \\
\text { age at } \\
\text { MS } \\
\text { onset } \\
\text { (years) }\end{array}$ & LAT & $\begin{array}{l}\text { NOS } \\
\text { Score }\end{array}$ & $\begin{array}{l}\text { MS Dx } \\
\text { criterion }\end{array}$ & $\begin{array}{l}\text { Timing } \\
\text { of } \\
\text { surgery }\end{array}$ & Confounder variables & $\begin{array}{c}\text { Exposure 1: } \\
\text { Tonsil OR } \\
(95 \% \mathrm{Cl})\end{array}$ & $\begin{array}{c}\text { Exposure 2: } \\
\text { Append OR }{ }^{1} \\
(95 \% \mathrm{Cl})\end{array}$ & $\begin{array}{c}\text { Exposure 3: } \\
\text { Adenoid OR }{ }^{1} \\
(95 \% \mathrm{Cl})\end{array}$ & $\begin{array}{c}\text { Exposure 4: } \\
\text { Other OR }{ }^{1} \\
(95 \% \mathrm{Cl})\end{array}$ \\
\hline 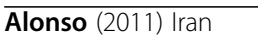 & 394 & 394 & 3.70 & 24.9 & 32 & 6 & $\mathrm{M}$ & Pre & Age, sex & $0.92(0.51-1.64)$ & $1.07(0.52-2.19)$ & - & - \\
\hline Alter (1968) USA & 36 & 72 & & & 45 & 4 & N & Pre & Age, sex, age at onset & - & - & - & $0.78(0.33-1.81)$ \\
\hline $\begin{array}{l}\text { Anderson (1981) } \\
\text { Denmark }\end{array}$ & 92 & 276 & 1.42 & 42.4 & 56 & 8 & $\begin{array}{c}\text { A; after 1994, } \\
\text { Mc }\end{array}$ & $\leq 20 y$ & $\begin{array}{l}\text { Age, sex, month of birth, } \\
\text { years in school }\end{array}$ & $0.73(0.32-1.64)$ & $0.81(0.22-2.98)$ & $1.08(0.64-1.82)$ & - \\
\hline $\begin{array}{l}\text { Antonovsky (1965) } \\
\text { Israel }\end{array}$ & 241 & 964 & 1.10 & & 31 & 5 & N & $\begin{array}{l}\leq 15 y \\
>15 y\end{array}$ & $\begin{array}{l}\text { Age, sex, age of onset, } \\
\text { region of birth }\end{array}$ & - & - & - & $\mathrm{NS}^{2}$ \\
\hline Bansil (1997) India & 56 & 147 & 1.67 & 28 & 24 & 3 & $P$ & Pre & $\begin{array}{l}\text { Birth place, religion, } \\
\text { residence }\end{array}$ & - & - & - & $0.97(0.49-1.91)$ \\
\hline Berr (1989) France & 63 & 63 & 2.70 & 30.8 & 42 & 5 & $P$ & Pre & Age, sex, residence & $1.0(0.38-2.60)$ & - & - & - \\
\hline $\begin{array}{l}\text { Bobowick (1978) } \\
\text { USA }\end{array}$ & 10 & 8 & & 29.7 & 40 & 6 & N & $\leq 20 y$ & Age, sex & $\begin{array}{l}2.50(0.37- \\
16.89)\end{array}$ & $5.0(0.21-120.4)$ & - & - \\
\hline $\begin{array}{l}\text { Broadley (2000) } \\
\text { England }\end{array}$ & 595 & 372 & 3.16 & 28 & 52 & 1 & N & Pre & None stated & $1.02(0.77-1.34)$ & - & - & - \\
\hline Casetta (1994) Italy & 104 & 150 & 2.0 & 32.2 & 44 & 5 & $\mathrm{Mc}$ & $\begin{array}{l}\leq 15 y \\
>15 y\end{array}$ & $\begin{array}{l}\text { Age }(>3 \text { y), sex } \\
\text { residence }\end{array}$ & $1.04(0.62-1.76)$ & - & - & - \\
\hline $\begin{array}{l}\text { Cendrowski (1969) } \\
\text { Poland }\end{array}$ & 300 & 300 & & 31.9 & 52 & 3 & N & $\leq 15 y$ & None stated & $0.74(0.43-1.27)$ & - & - & - \\
\hline $\begin{array}{l}\text { Currier (1982) } \\
\text { Canada \& USA }\end{array}$ & 40 & 40 & 1.0 & 30 & 49 & 5 & A & Pre & Age, sex & - & - & - & $2.22(0.86-5.74)$ \\
\hline Currier (1974) Ireland & 60 & 60 & 1.4 & 26 & 53 & 3 & A & $\leq 20 y$ & $\begin{array}{l}\text { Age, sex, social class, } \\
\text { marital status }\end{array}$ & $1.18(0.53-2.61)$ & $1.46(0.54-3.93)$ & - & $1.45(0.62-3.41)$ \\
\hline \multirow{4}{*}{$\begin{array}{l}\text { de Gennaro (2009) } \\
\text { Italy \& Serbia }\end{array}$} & \multirow[t]{4}{*}{104} & \multirow[t]{4}{*}{150} & \multirow[t]{4}{*}{2.06} & \multirow[t]{4}{*}{28} & \multirow[t]{4}{*}{44} & \multirow[t]{4}{*}{3} & \multirow[t]{4}{*}{ M } & \multirow{4}{*}{$\begin{array}{l}\leq 15 y \\
>15 y\end{array}$} & \multirow[t]{4}{*}{ Age, sex, residence } & $\leq 15 \mathrm{y}: 2.50$ & $<15$ y: 1.60 & \multirow[t]{4}{*}{-} & \multirow[t]{4}{*}{-} \\
\hline & & & & & & & & & & $(1.42-4.41)^{*}$ & $(0.91-2.79)$ & & \\
\hline & & & & & & & & & & $>15 \mathrm{y}:$ & $>15 \mathrm{y}:$ & & \\
\hline & & & & & & & & & & $2.20(1.30-3.73)^{*}$ & $1.92(1.09-3.41)^{*}$ & & \\
\hline da Silva (2009) Brazil & 81 & 81 & 2.10 & & 22 & 4 & N & Pre & Age, sex, place of birth & - & - & - & $1.82(0.95-3.51)$ \\
\hline Dolan (2003) USA & 24 & 24 & 2.0 & 35.4 & 42 & 3 & $P$ & $\leq 20 y$ & Age, sex & - & - & - & $2.14(0.63-7.33)$ \\
\hline
\end{tabular}


Table 1 Characteristics of included studies (Continued)

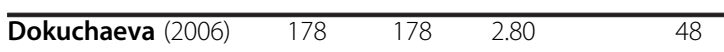

Russia

$\begin{array}{lcccccc}\begin{array}{l}\text { Gronning (1993) } \\ \text { Norway }\end{array} & 155 & 200 & 1.50 & - & 60 & 4 \\ \text { Gusev (1996) Russia } & 155 & 155 & 1.63 & 25.8 & 56 & 3 \\ & & & & & & \\ \text { Hopkins (1991) USA } & 14 & 56 & 4.30 & 35.2 & 41 & 7 \\ \begin{array}{l}\text { Koch (1974) USA } \\ \text { Koch-Henriksen }\end{array} & 7 & 7 & 2.50 & 29.3 & 46 & 4 \\ \text { (1989) Denmark } & & 297 & 1.42 & 32 & 56 & 8 \\ \end{array}$

\section{Kurtzke}

Lamoureux (1976)

Canada

Lauer (1994)

Germany

\section{Martinez-Sobrepera}

(2001) Cuba

Poskanzer (1980)

USA

$\begin{array}{llllll}\text { Poskanzer (1965) } & 210 & 210 & 1.31 & 33.6 & 60\end{array}$

Scotland

$\begin{array}{llllll}\text { Roshanisefat (2011) } & 20,542 & 204,157 & 1.87 & 46.3 & -\end{array}$

Sweden

Westlund (1953)

Canada

No data

$\leq 15 y$,
$>15 y$

$>15 y$

Age, sex, ethnic origin

$\leq 15$ y: 1.61

$>15 \mathrm{y}$ :

$\begin{array}{ccc}\text { B } & \leq 20 y & \text { Age, sex, residence } \\ \text { MC } & \begin{array}{cc}\leq 15 y, \\ >15 y\end{array} & \text { Age, sex, residence, and } \\ & \text { Pre } & \text { Age, sex, race } \\ \text { P } & \text { Pre } & \text { None stated } \\ N & \leq 15 y, & \text { Age, sex } \\ \text { A } & >15 y & \end{array}$

Schumacher committee

Pre

Pre

Pre

Age, sex, place of origin

Age, sex, type of residence

Pre Age, gender, skin color

Pre

None stated

$\leq 20 y$

Age, sex, residence

$\leq 20 \mathrm{y}$

$>20 y$

Age, sex, age at onset, region

Pre Age, sex, age at onset

Pre
$1.0(0.64-1.56)$

$1.90(1.15-3.16)^{*} \quad 1.10(0.53-2.28)$

$0.85(0.38-1.89)$

$-$

$\leq 15 \mathrm{y}:$

$0.89(0.52-1.53)$

$$
>15 \mathrm{y} \text { : }
$$$$
\begin{gathered}
- \\
\leq 15 y:
\end{gathered}
$$

$\mathrm{NS}^{2}$

$1.0(0.12-8.31)$

$\leq 15 \mathrm{y}:$

$1.49(0.72-3.08) \quad 1.24(0.70-2.21)$$$
\begin{aligned}
& 3.56(1.05- \\
& 12.05)
\end{aligned}
$$

$3.05(0.78-11.96)$

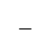

$N S^{2}$

$$
-
$$$$
N S^{2}
$$$$
-
$$

$1.69(1.15-2.50)^{*}$

\section{$1.42(0.86-2.35)$}

$$
\leq 20 \mathrm{y} \text { : }
$$

$1.11(0.94-1.31)$

$$
>20 \mathrm{y} \text { : }
$$

$1.02(0.93-1.11)$$$
-
$$ 
Table 1 Characteristics of included studies (Continued)

YosefiPour (2002)

$3.93(1.97-7.84)$

Iran

Zaadstra (2008)

Netherlands

Zilber (1996) Israe

$2,821 \quad 2,550$

2.30

$-\quad 52 \quad 7$
-20

N

$<25 y$

Age, sex, education, residence

$\begin{array}{lllll}70 & 64 & 1.73 & 25.2 & 31\end{array}$

6

M

$\leq 20 y$,

Age, sex

$1.25(1.11-1.40)^{*}$

$$
\leq 20 \mathrm{y} \text { : }
$$

$-$

$<10$ y:3.0 $(0.77-$

$0.58(0.29-1.17)$

$1.06(0.47-2.39)$

11.62)

Pre: $0.96(0.44-$

2.11)

Zorzon (2003) Italy

140

131

$1.72 \quad 31.2$

$45 \quad 5$

M

Pre

None stated

$-$

$0.46(0.28-0.76)$

'Odds ratio for combined surgeries using a random effects model.

2 Reported as not statistically significant, no data provided.

* Indicates statistically significant results.

$\mathbf{A}=$ Allison \& Miller criteria, $\mathbf{A p p e n d}=$ appendectomy, $\mathbf{A d e n o i d}=$ adenoidectomy, $\mathbf{B}=$ Bauer criteria, $\mathbf{C l}=$ confidence interval, $\mathbf{D x}=$ diagnosis, $\mathbf{L} \mathbf{A T}=$ latitude, $\mathbf{M c}=\mathbf{M c A l p i n e}$ criteria, $\mathbf{M}=\mathbf{M c D o n a l d}$ criteria, $\mathbf{M S}=$ multiple

sclerosis, NOS = Newcastle-Ottawa Scale, $\mathbf{N}=$ neurologist diagnosed, $\mathbf{N S}=$ not significant, $\mathbf{O R}=$ odds ratio, $\mathbf{P}=$ Poser criteria, Pre: Premorbid, age not specified other than surgery occurring before MS diagnosis,

Tonsil $=$ tonsillectomy, $\mathbf{Y}=$ years. 


\section{Effect measurement and data synthesis}

Meta-analyses were performed using the Cochrane Collaboration software program Review Manager (Rev Man) Version 5.1 [18]. To estimate the strength of association between surgery exposure variables and risk for MS diagnosis, data were pooled using the inverse variance (IV) approach to calculate the OR and 95\% CIs and statistical significance was set at $p<0.05$. When interpreting results of the forest plots for dichotomous data, the area to the right side of the forest plot graph $(>1)$ favoured the control group. Studies were weighted based on sample size and the number of events.

Meta-analyses methods were selected based on study heterogeneity and the number of studies included in the analyses. When the $\mathrm{I}^{2}$ statistic was greater than $75 \%$, we considered it substantial heterogeneity and pooled the study results using a RE model [19].

\section{Subgroup analysis and investigation of heterogeneity}

A priori, we planned to explore and address possible clinical heterogeneity as well as to investigate the magnitude and precision of effects by performing sub-group analyses based on type of surgery (tonsillectomy, appendectomy, adenoidectomy, other surgery), and age at time of surgery ( $\leq 20$ years of age and those $>20$ years of age). Sub-group analyses were also performed on reported association (number of covariates), female to male sex ratio, NOS score, latitude, and age at MS onset.

\section{Sensitivity analysis}

We performed sensitivity analyses by examining the results of the meta-analysis under different assumptions and checked for robustness of the observed findings. $A$ priori, the following sensitivity analyses were planned:

1. By limiting included studies in the analyses to those with the highest methodological quality, do the results change?

2. For studies in which the OR was reported as "not significant" and therefore had to be imputed, do the results of the pooled analysis change if these are excluded from the results?

\section{Results}

\section{Characteristics of included studies}

After excluding duplicate studies, we identified 100 individual studies, of which 75 were potentially relevant. Of these, despite our best attempts to contact primary or corresponding authors, eight studies could not be located [20-27]; therefore, 67 potentially relevant full text articles were retrieved for closer examination. Of the retrieved articles, 34 were excluded for the following reasons: 18 did not examine surgery as a risk factor [28-45]; six did not have a control group [46-51]; five were review articles [52-56]; four were not specific to MS [57-60]; and one had insufficient data, and we were unable to locate study authors [61]. A total of 33 studies were identified which met the inclusion criteria for the systematic review [62-94]. One additional cohort study was found but was not included due to heterogeneity in study design and exposure [95]. Figure 1 outlines the study selection process.

All of the included studies were case-control studies and were published between 1953 and 2011. Seventeen individual studies reported tonsillectomy data [62,64, $67-69,71,73,75,76,78,79,82,84,87,88,92,93], \quad 11$ reported appendectomy data $[62,64,68,73,75,78,82,84,85,87,89]$, three reported adenoidectomy data $[64,82,93]$, and 18 reported on other surgeries [63,65,66,70,72-74,77,80, $81,83,85,86,88,90,91,93,94]$. The majority of the studies (17 studies) were published in European countries $[64,67,69-71,73,75,78,82,83,85,87,89,92-94]$, followed by nine in North America [63,68,72,77,80,81,84,88,90], four published in the Middle East [62,65,91,93], and lastly one each from India [66], Brazil [74], and Cuba [86].

Exposure risks for MS were reported as ORs in most of the studies while others simply reported whether the exposure risk for MS was "significant" or "not significant" $[65,80,81,85,88]$. The ORs ranged from 0.46 to 5.0 depending on the type of surgery reported. Eight independent studies reported statistically significant results for specific exposures $[75,78,85,87,90-92,94]$, while the remaining 25 did not. See characteristics of included studies in Table 1.

\section{Quality assessment}

Included studies were classified according to the NOS with seven studies considered high risk of bias [66,69,71,73,75,77,79]; 16 studies had a medium risk of bias $[63,65,67,70,72,74,78,81,83-86,88,90,91,94]$; and nine studies had a low risk of bias $[62,64,68,80,82,87,89,92$, 93]. One study could not be assessed due to lack of included data [76].

\section{Exposure results}

The meta-analysis included data from all 33 studies with 27,373 MS cases and 211,756 controls; there were twice as many females than males included in the studies and the mean age of MS diagnosis was 31 years. See Table 2 for pooled surgery exposure results.

\section{Tonsillectomy}

Of the 17 separate studies reporting on tonsillectomy, 12 examined tonsillectomy at age $\leq 20$ and 9 examined tonsillectomy at age $>20$, or simply "premorbid". Pooled analyses displayed statistical heterogeneity hence the estimates were based on the RE model. 


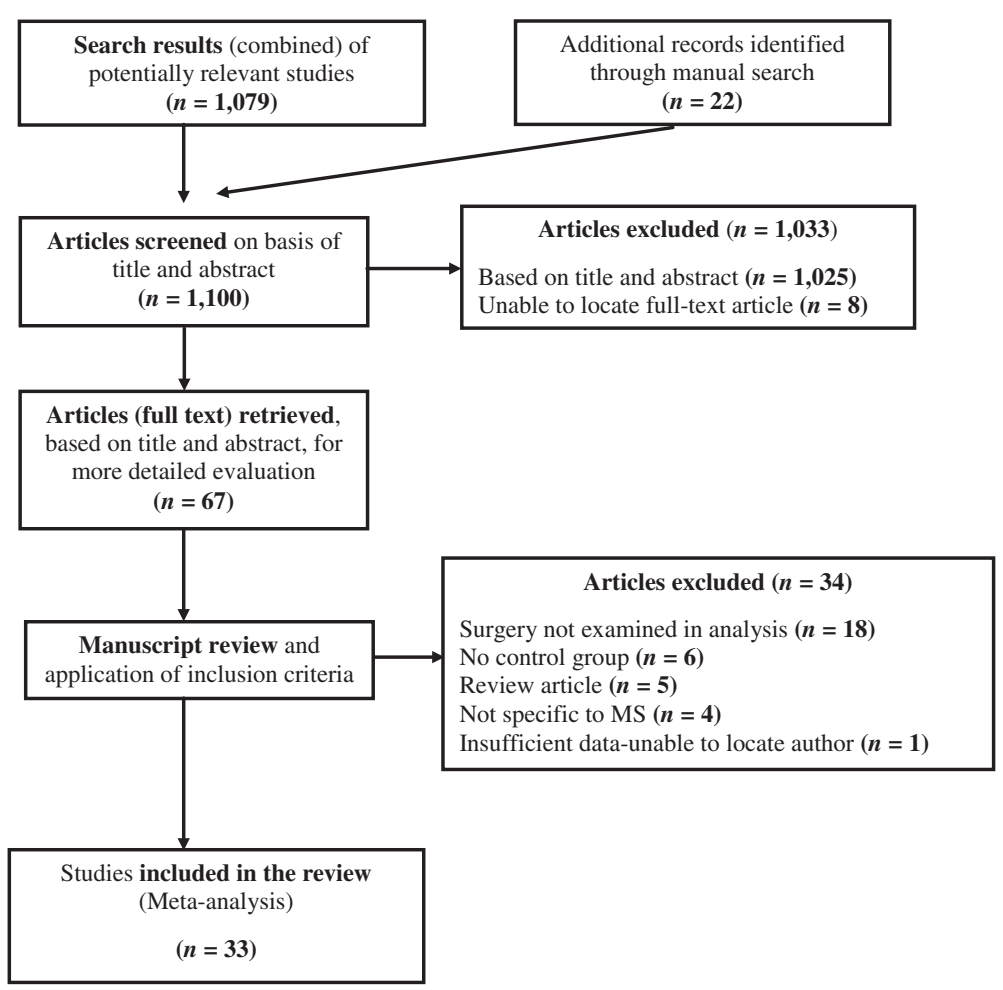

Figure 1 Flow diagram of study selection.

The 12 studies examining tonsillectomy at age $\leq 20$ included 4,414 MS cases and 4,422 controls. The pooled RE model revealed moderate heterogeneity in the sample $\left(\mathrm{I}^{2}=44 \% ; p=0.05\right)$ and a statistically significant relationship between tonsillectomy and MS onset $(\mathrm{OR}=1.32$; 95\% CI, 1.08-1.61; $p=0.006$ ). To further explore heterogeneity, we conducted a sensitivity analysis based on study quality (removing those studies with a NOS score $<6$ ). Although removing the six studies with a NOS score of $<6$ provided a more homogenous sample $\left(\mathrm{I}^{2}=12 \% ; p=0.34\right)$ the difference was not significant as the direction and magnitude of the effect did not change
$(\mathrm{OR}=1.29 ; 95 \% \mathrm{CI}, 1.08-1.53 ; p=0.005)$; therefore, we included all 12 studies in the final analysis. Sensitivity analysis based on removing the one study where the OR was imputed did not change the significance nor magnitude of the effect $(\mathrm{OR}=1.27 ; 95 \% \mathrm{CI}, 1.02-1.58$; $p=0.03$ ); therefore, we included all 12 studies in the final analysis. Forest plot results for tonsillectomy exposure occurring at $\leq 20$ years of age are presented in Figure 2.

The nine studies examining tonsillectomy in pa tients' $>20$ years or "premorbid" included 1,801 MS cases and 1,618 controls. The RE model revealed a

Table 2 Odds ratios for pooled surgery exposures using a random effects model

\begin{tabular}{|c|c|c|c|c|c|c|c|}
\hline Exposure & $\begin{array}{l}\text { Included } \\
\text { studies } \\
\text { (n) }\end{array}$ & $\begin{array}{c}\text { MS } \\
\text { case } \\
\text { group } \\
\text { (n) }\end{array}$ & $\begin{array}{l}\text { Control } \\
\text { group } \\
\text { (n) }\end{array}$ & $\begin{array}{l}\text { Total } \\
\text { (n) }\end{array}$ & $\begin{array}{c}\text { Level of } \\
\text { heterogeneity } \\
I^{2}\left(X^{2} p\right)\end{array}$ & $\begin{array}{c}\text { Pooled OR } \\
(95 \% \mathrm{Cl})\end{array}$ & $\begin{array}{c}\text { Test for overall effect } \\
\qquad(p)\end{array}$ \\
\hline Tonsillectomy $\leq 20$ years & 12 & 4,414 & 4,422 & 8,836 & $44 \%(0.05)$ & $1.32(1.08-1.61)^{*}$ & $2.76(0.006)^{*}$ \\
\hline Tonsillectomy $>20$ years & 9 & 1,801 & 1,618 & 3,419 & $32 \%(0.16)$ & $1.20(0.94-1.53)$ & $1.45(0.15)$ \\
\hline Appendectomy $\leq 20$ years & 7 & 21,218 & 205,124 & 226,342 & $0 \%(0.54)$ & $1.16(1.01-1.34)^{*}$ & $2.06(0.04)^{*}$ \\
\hline Appendectomy $>20$ years & 5 & 21,360 & 205,021 & 226,381 & $46 \%(0.11)$ & $1.26(0.92-1.72)$ & $1.43(0.15)$ \\
\hline Adenoidectomy $\leq 20$ years & 3 & 458 & 636 & 1,094 & $35 \%(0.21)$ & $1.06(0.68-1.68)$ & $0.27(0.79)$ \\
\hline Surgery $\leq 20$ years & 4 & 485 & 1,202 & 1,687 & $19 \%(0.30)$ & $0.95(0.70-1.31)$ & $0.29(0.77)$ \\
\hline Surgery $>20$ years & 15 & 1,099 & 1,371 & 2,470 & $71 \%(0.0001)$ & $1.19(0.83-1.70)$ & $0.94(0.35)$ \\
\hline
\end{tabular}

* Indicates statistically significant results at $p<0.05$.

$\mathbf{C l}=$ confidence interval, $\mathbf{M S}=$ multiple sclerosis, $\mathbf{O R}=$ odds ratio. 
homogeneous sample $\left(\mathrm{I}^{2}=32 \% ; p=0.16\right)$ with no statistical difference between the groups $(\mathrm{OR}=1.20$; $95 \% \mathrm{CI}$, $0.94-1.53 ; p=0.15)$. When four studies with a NOS score of $<6$ were excluded, the pooled results became more homogeneous $\left(\mathrm{I}^{2}=0 \% ; p=0.88\right)$ but the magnitude and the significance of the results did not change $(\mathrm{OR}=1.04$; 95\% CI, 0.78-1.37; $p=0.85$ ). All nine studies reported exact OR data thus, sensitivity analysis, based on the imputation of data, was not required and all nine studies were included in the final analysis.

\section{Appendectomy}

Eleven separate studies examined appendectomy; nine examined appendectomy in those $\leq 20$ years and five examined appendectomy at age $>20$, or "premorbid". Pooled analyses displayed statistical heterogeneity, for that reason the estimates were based on the RE model.

The nine studies examining appendectomy in those $\leq$ 20 years included 21,574 MS cases and 205,480 controls. Moderate heterogeneity $\left(\mathrm{I}^{2}=48 \% ; p=0.05\right)$ of the $\mathrm{RE}$ pooled results was demonstrated with no statistical relationship between appendectomy in those $\leq 20$ and MS onset $(\mathrm{OR}=1.16$; 95\% CI, 0.87-1.53; $p=0.31)$. We further conducted sensitivity analysis based on study quality. Although removing the five studies with a NOS score of $<6$ provided a more homogenous sample $\left(\mathrm{I}^{2}=13 \%\right.$; $p=0.33)$ the difference was not significant as the magnitude and precision of the effect did not change (OR = $1.21 ; 95 \% \mathrm{CI}, 0.87-1.69 ; p=0.27)$. Sensitivity analysis based on removing two studies where the ORs were imputed reduced the heterogeneity $\left(\mathrm{I}^{2}=0 \% ; p=0.54\right)$ and changed the significance of the result $(\mathrm{OR}=1.16 ; 95 \%$ CI, $1.01-1.34 ; p=0.04$ ) thus, we used the reduced, statistically significant model in the final analysis.

The five studies examining appendectomy occurring in those patients $>20$ years or "premorbid" included 21,360 MS cases and 205,021 controls. The RE model revealed a moderately homogeneous sample $\left(\mathrm{I}^{2}=46 \% ; p=0.11\right)$ with no statistical difference between groups $(\mathrm{OR}=1.26$; 95\% CI, 0.92-1.72; $p=0.15)$. When studies with a NOS score of $<6$ were excluded, the results did not change. All five studies reported exact OR data, consequently, sensitivity analysis based on the imputation of ORs was not required and all five studies were included in the final analysis.

\section{Adenoidectomy}

Three studies, involving $458 \mathrm{MS}$ cases and 636 controls, reported on adenoidectomy in patient's $\leq 20$ years. The RE model revealed a homogeneous sample $\left(\mathrm{I}^{2}=35 \%\right.$; $p=0.21$ ) with no statistical difference between groups (OR $=1.06$; 95\% CI, 0.68-1.68; $p=0.79$ ). All three studies were of high quality and all reported exact OR data, as a result, sensitivity analyses were not required.

\section{Surgery}

Eighteen discrete studies examined "other surgery"; four examined surgery occurring in those $\leq 20$ years and 15 
examined surgery in patients $>20$, or "premorbid". Pooled analyses displayed statistical heterogeneity thus the estimates were based on the RE model.

The four studies reporting on other surgery occurring in subject's $\leq 20$ years included 485 MS cases and 1,202 controls. The RE model revealed a homogeneous sample $\left(\mathrm{I}^{2}=19 \% ; p=0.30\right)$ with no statistical difference between groups $(\mathrm{OR}=0.95 ; 95 \% \mathrm{CI}, 0.70-1.31 ; p=0.77)$. Sensitivity analysis, based on study quality, was not done as all but one of the four studies had a NOS score of $<6$. Further sensitivity analysis, excluding those studies that did not report a specific OR, did not significantly change the results $(\mathrm{OR}=1.01 ; 95 \% \mathrm{CI}, 0.28-3.57 ; p=0.99)$.

The 15 studies examining other surgery in patients $>20$, or "premorbid" included 1,099 MS cases and 1,371 controls. Significant heterogeneity $\left(\mathrm{I}^{2}=71 \%\right.$; $p<0.0001)$ of the RE pooled results was demonstrated; regardless, there were no statistical differences between groups $(\mathrm{OR}=1.19 ; 95 \% \mathrm{CI}, 0.83-1.70 ; p=0.35)$. Sensitivity analysis, based on study quality, was not done as all but two of the 15 included studies had a NOS score of $<6$. Further sensitivity analysis, excluding those studies that did not report a specific OR, did not significantly change the results $(\mathrm{OR}=1.32$; $95 \% \mathrm{CI}, 0.92-1.91$; $p=0.14)$.

\section{Examining bias}

To visually assess for heterogeneity, we plotted the ORs of high quality versus low quality studies. The plot showed no distinct linear relationship between methodological quality of studies (NOS score) and ORs, with no obvious clustering, indicating a low risk of bias.

For the tonsillectomy exposure ( $\leq 20$ years), the test for publication bias was not statistically significant $(p=0.94)$, with a symmetrical funnel plot indicating a low risk for publication bias [96]. For the surgery premorbid exposure, the test for publication bias was also not statistically significant $(p=0.62)$; although, the plot was more asymmetrical indicating the potential for publication bias. Given the small number of studies included in the other exposures ( $<10$ studies), the interpretation of funnel plots must be undertaken with caution and are therefore not included here.

\section{Meta-regression}

Results from the meta- regression are presented in Table 3. Meta-regression was performed on the subgroups including at least 10 studies, namely tonsillectomy at age $\leq 20$ and premorbid "surgery". None of the variables entered into the regression analysis, for the surgery premorbid exposure, reached statistical significance therefore not significantly influencing the effect sizes. For the tonsillectomy at age $\leq 20$, only one of the variables, the number of covariates adjusted for ( $\leq 2$ vs. $>2$ ), reached statistical significance $(\beta=1.64 ; 95 \% \mathrm{CI}, 1.02$ 2.62). That is, the effect size or risk for MS diagnosis increased as the number of covariates that were adjusted for (in the individual included studies) increased. This further indicates limited residual heterogeneity after controlling for the influence of latitude, female to male sex ratio, mean age of MS onset, NOS score, language, publication status, and sample size. Although not a statistically significant finding $(p=0.45)$, the tonsillectomy exposure, in those $\leq 20$ years, increased as the female to male ratio increased.

\section{Discussion}

Overall, the evidence presented in this review supports a relationship between tonsillectomy and appendectomy in childhood and the subsequent risk of MS. More specifically, those with tonsillectomy or appendectomy at $\leq$ 20 years of age were approximately $30 \%$ more likely to be diagnosed with MS in comparison to similar patients who did not have a tonsillectomy or appendectomy at $\leq$ 20 years of age. The findings of this review do not support an association between tonsillectomy or appendectomy occurring in those $>20$ years, adenoidectomy, and "other surgery" occurring at any age and the subsequent risk for the onset of MS. Although we did not find an association between these variables and risk for MS, it is important to note that due to the multi-factorial and heterogeneous nature of MS, surgery may indeed pose a slight risk for certain individuals.

Several theories linking tonsillectomy to MS risk have been postulated over the years. Meurman and Wising [39] proposed tonsillectecomy as a possible risk factor for MS in that an upper respiratory tract infection may trigger MS or that a locally deficient immune system may facilitate the invasion of an etiologically relevant, infectious agents. Tonsillectomy may leave sufficient lymphoid tissue adjacent to the central nervous system to instigate the exaggerated immune response seen in MS [39,69,87]. Poskanzer (1965) was particulary interested in examining tonsillectomy and MS risk at it predisposes to the development of neurological complications in poliomyelitis, another infection that is much more widespread than is suggested by its neurological manifestations [87,97-99].

Of particular interest is the association between recurrent tonsillitis and EBV infection and reactivation [100]. A recent meta-analysis of case-control and cohort studies found a statistically significant combined relative risk (RR) for MS in those with a past history of infectious mononucleosis ( $R R=2.17$; 95\% CI, 1.97-2.39) [101]. Furthermore, others have found statistically significant elevated levels of antibody to some common infectious agents, other than EBV, in children and adults with MS compared to controls [92,102-104]. Krone and collegues 
Table 3 Sensitivity analyses and stratified meta-regression for assessing heterogeneity among case-control studies looking at the exposures tonsillectomy in childhood and "surgery" premorbid ${ }^{1}$

\begin{tabular}{|c|c|c|c|c|c|c|c|c|c|c|}
\hline \multirow[t]{3}{*}{ Exposure variables } & \multicolumn{5}{|c|}{ Tonsillectomy - childhood } & \multicolumn{5}{|c|}{ Surgery - premorbid } \\
\hline & \multicolumn{2}{|c|}{ Studies } & \multirow{2}{*}{$\begin{array}{c}\text { Sub-group } \\
\text { OR }(95 \% \mathrm{CI})^{2}\end{array}$} & \multicolumn{2}{|c|}{ Meta-regression } & \multicolumn{2}{|c|}{ Studies } & \multirow{2}{*}{$\begin{array}{c}\text { Sub-group } \\
\text { OR }(95 \% \mathrm{Cl})^{2}\end{array}$} & \multicolumn{2}{|c|}{ Meta-regression } \\
\hline & $\bar{n}$ & Total $(n)$ & & $p$ & $\beta(95 \% \mathrm{Cl})^{3}$ & $\bar{n}$ & Total $(n)$ & & $p$ & $\beta(95 \% \mathrm{Cl})^{3}$ \\
\hline \multicolumn{11}{|l|}{ Population-level characteristics } \\
\hline Latitude & 12 & 8,836 & $1.32(1.08-1.61)^{*}$ & 0.79 & $1.00(0.96-1.03)$ & 15 & 2,470 & $1.19(0.83-1.70)$ & 0.89 & $1.00(0.97-1.03)$ \\
\hline \multicolumn{11}{|l|}{ (geographic) } \\
\hline Female: Male & 10 & 8,218 & $1.39(1.15-1.68)^{*}$ & 0.45 & $1.20(0.71-2.04)$ & 14 & 2,362 & $1.22(0.84-1.79)$ & 0.91 & $0.98(0.64-1.48)$ \\
\hline Mean age of MS onset & 9 & 2,818 & $1.17(0.85-1.61)$ & 0.51 & $0.98(0.90-1.06)$ & 10 & 1,551 & $1.12(0.77-1.63)$ & 0.53 & $0.94(0.77-1.16)$ \\
\hline \multicolumn{11}{|l|}{ Study-level characteristics } \\
\hline NOS score & 11 & 8,480 & $1.29(1.03-1.60)^{*}$ & 0.77 & $0.98(0.85-1.13)$ & 15 & 2,470 & $1.19(0.83-1.70)$ & 0.58 & $0.89(0.58-1.37)$ \\
\hline NOS score $(<6$ vs. $\geq 6)$ & 12 & 8,836 & $1.32(1.08-1.61)^{*}$ & 0.60 & $0.88(0.51-1.50)$ & 15 & 2,470 & $1.19(0.83-1.70)$ & 0.84 & $0.84(0.13-5.57)$ \\
\hline Language (English vs. non-English) & 12 & 8,836 & $1.32(1.08-1.61)^{*}$ & 0.10 & $0.62(0.34-1.12)$ & 15 & 2,470 & $1.19(0.83-1.70)$ & 0.73 & $0.78(0.17-3.61)$ \\
\hline Pub type (published vs. unpublished) & 12 & 8,836 & $1.32(1.08-1.61)^{*}$ & 0.09 & $0.50(0.22-1.13)$ & 15 & 2,470 & $1.19(0.83-1.70)$ & & $N / A^{4}$ \\
\hline Number of covariates ${ }^{5}(\leq 2$ vs. $>2)$ & 12 & 8,836 & $1.32(1.08-1.61)^{*}$ & 0.04 & $1.64(1.02-2.62)^{*}$ & 15 & 2,470 & $1.19(0.83-1.70)$ & 0.73 & $0.88(0.39-1.96)$ \\
\hline Sample size $(\leq 100$ vs. $>100)$ & 12 & 8,836 & $1.32(1.08-1.61)^{*}$ & 0.54 & $0.52(0.05-5.27)$ & 15 & 2,470 & $1.19(0.83-1.70)$ & 0.56 & $0.76(0.29-2.01)$ \\
\hline MS cases ( $\leq 100$ vs. $>100)$ & 12 & 8,836 & $1.32(1.08-1.61)^{*}$ & 0.37 & $1.32(0.68-2.60)$ & 15 & 2,470 & $1.19(0.83-1.70)$ & 0.70 & $0.87(0.40-1.90)$ \\
\hline
\end{tabular}

1 All analyses weighted by sample size.

2 OR $(95 \% \mathrm{Cl})$ were calculated using the random effects model in RevMan.

${ }^{3} \beta(95 \% \mathrm{Cl})$ were calculated using the study level log OR and the SE of the estimate (calculated in RevMan) by univariate random effects meta-regression in STATA 12 using the megareg command.

${ }^{4}$ All studies were published - analysis not warranted.

${ }^{5}$ Number of potentially confounding variables adjusted for in individual studies.

$\mathbf{C l}=$ confidence interval, $\mathbf{M S}=$ multiple sclerosis, $\mathbf{N O S}=$ Newcastle-Ottawa Scale, $\mathbf{O R}=$ odds ratio, Pub $=$ Publication, $\mathbf{S E}=$ Standard error .

[104] postulate that these findings reflect a dysregulation of immune function as a consequence of the development of the disease. They assert that immune dysregulation in MS is likely to be an early event preceding the onset of MS disease by many years or even decades $[14,105,106]$. It is likely that the elevated antibody concentrations do not directly cause MS but rather reflect a shift in patterns of immune reactivity away from protection towards enhancement of the risk of disease. These authors suggest that studies on MS-associated infectious agents could lead to the identification of specific antigenic determinants involved in the generation and maintenance of immune dysregulation.

There seems to be similarities between MS and appendicitis, which often results in appendectomy. More recently, scientists have recognized the role of the appendix as part of the body's immune system, as it contains white blood cells and acts as a reservoir for "good" bacteria for the gut [107]. The role of the appendix is to contain "good bacteria"; when bacteria in the intestines die or are purged from dysentery or cholera, the "good bacteria" are replaced from the stores in the appendix. As a result, appendicitis (inflammation of the appendix) may indicate inadequate immunological function $[84,89,108]$; thereby providing an association of both EBV and appendicitis (resulting in appendectomy) with MS [109-111]. Immunological reaction relevant to appendicitis may indicate MS risk as activation of peripheral blood mononuclear cells, including those causing inflammatory destruction of myelin, which occurs in lymphoid tissue $[89,108]$. Appendicitis is a marker of immune characteristics influencing immunemediated disease risk, as it has a direct role in the development of ulcerative colitis $[89,112,113]$. Further, CD8+ T-cell deficiency is a feature of both ulcerative colitis and MS [114].

There seems to be other possible similarities between MS and appendicitis. First, appendicitis and MS are autoimmune diseases. Both appendicitis and MS are diseases associated with industrialized countries but not developing countries [115,116]. MS is a disease largely prevalent in Europe, North America, Australia, and New Zealand, but is rare among Asians and Africans [116]. Lastly, several epidemiological and experimental studies support the hygiene hypothesis in both appendicitis $[115,117]$ and MS $[109,118]$, which postulates that immunopathology may be an unanticipated consequence of advances in sanitation and public health $[109,118,119]$.

\section{Quality of the evidence}

One of the main challenges of the review related to the varying definitions of "surgery" in the included studies. Some studies included only tonsillectomy or appendectomy, and some included all surgeries. More importantly, the number of surgeries in individual patients (prior to MS onset) would have been a significant 
variable to assess; however, none of the included studies reported this as a potential risk factor. Another potential limitation pertained to the fact that, with the exception of a single study [89], the majority of studies reporting on appendectomy did not indicate the reason for surgery; therefore, we had to assume that appendectomy was as a result of appendicitis (infection / inflammation). It must be emphasized that characterizing appendectomy, by underlying diagnosis, may be important when assessing true MS risk.

Ideally, in case-control studies, cases should be representative of the entire population and be identified by independent MS diagnostic criteria. Controls should be randomly selected within the community of the residing representative MS cases. Only nine case-control studies examined in this review selected controls from the community $[64,65,67,79,80,82,88,90,93]$. To further control for bias, control subjects should have no prior history of disease, representing healthy individuals of the same socio-economic class.

Age at disease onset is very important in MS etiologic studies and ought to have been used as a matching variable to potentially control for bias. The age at disease diagnosis is used to allow researchers a timeframe to assess for potential exposure to associated agents. Ideally, case-control matching ought to be done for universal variables such as age, sex, and age at MS diagnosis. Other matching variables to be considered in MS studies include residence and place of birth. Interviewer blinding, another means of controlling for bias, was done by only one study [94].

\section{Potential bias in the review process}

The two review authors who assessed the methodological quality were not blinded for authors, journal, or institution. The potential bias caused by the nonblinded quality assessment was expected to be low as neither review author had a conflict of interest. Specifically, the review authors did not have any (financial or other) interest in positive or negative results. Furthermore, we searched the grey literature extensively for eligible studies, presented the search strategy and the inclusion criteria list, and all of the final results of the assessment, so that readers can make their own determinations of the results and our conclusions.

There is a possibility of publication bias or study selection bias in this meta-analysis. For example, by missing unpublished negative studies we may be over-estimating the association between prior surgery and the risk for developing MS. However, a comprehensive search of the published literature for potentially relevant studies was conducted, using a systematic strategy to avoid bias. This was followed by attempts to contact corresponding and first authors, as we recognize that unpublished or negative studies may exist.

\section{Conclusion}

This result of this meta-analysis suggests a statistically significant and clinically important increased risk for developing MS in those with tonsillectomy and appendectomy at $\leq 20$ years of age. Despite this significant finding, this in no way suggests or demonstrates causality, in that epidemiological studies can only provide etiological clues at best. More rigorous prospective studies, with high statistical power, are needed to prove an effect. Future prospective studies, that take into consideration the long latency period between the age of putative biological onset and clinical onset of MS, are needed in order to definitively rule out any links between tonsillectomy (or other surgeries) and MS.

\section{Competing interests}

The authors have no financial, personal, or any other kind of competing interests with this paper.

\section{Authors' contributions}

Study concept and design: CL, JAK-S, and SF; acquisition and preparation of data: $\mathrm{CL}$; analysis and interpretation of the data: $\mathrm{CL}, \mathrm{JAK}-\mathrm{S}$, and SF; risk of bias assessment: $\mathrm{CL}$ and JAK-S; first draft of the manuscript: CL. All authors critically reviewed the manuscript and approved the final version of the manuscript to be published.

\section{Authors' note}

We would be grateful if readers would send us reprints of any published or unpublished studies on multiple sclerosis and surgeries that have not been included in this paper, as well as any additional data missed from the included studies.

\section{Funding}

This study was supported by the Academic Research Fund of Athabasca University.

Received: 24 October 2012 Accepted: 22 April 2013

Published: 6 May 2013

\section{References}

1. Compston A, Coles A: Multiple sclerosis. Lancet 2002, 359(9313):1221-1231.

2. Whetten-Goldstein K, Sloan FA, Goldstein LB, Kulas ED: A comprehensive assessment of the cost of multiple sclerosis in the United States. Mult Scler 1998, 4(5):419-425.

3. Poser CM, Paty DW, Scheinberg L, McDonald WI, Davis FA, Ebers GC, Johnson KP, Sibley WA, Silberberg DH, Tourtellotte WW: New diagnostic criteria for multiple sclerosis: guidelines for research protocols. Ann Neurol 1983, 13(3):227-231.

4. McDonald WI, Compston A, Edan G, Goodkin D, Hartung HP, Lublin FD, McFarland HF, Paty DW, Polman CH, Reingold SC, Sandberg-Wollheim M, Sibley W, Thompson A, van den Noort S, Weinshenker BY, Wolinsky JS: Recommended diagnostic criteria for multiple sclerosis: guidelines from the International Panel on the diagnosis of multiple sclerosis. Ann Neurol 2001, 50(1):121-127.

5. Banwell B, Bar-Or A, Arnold DL, Sadovnick D, Narayanan S, McGowan M, O'Mahony J, Magalhaes S, Hanwell H, Vieth R, Tellier R, Vincent T, Disanto G, Ebers G, Wambera K, Connolly MB, Yager J, Mah JK, Booth F, Sebire G, Callen D, Meaney B, Dilenge M-E, Lortie A, Pohl D, Doja A, Venketaswaran S, Levin S, MacDonald EA, Meek D, et al: Clinical, environmental, and genetic determinants of multiple sclerosis in children with acute demyelination: a prospective national cohort study. Lancet Neurol 2011, 10(5):436-445. 
6. Handel AE, Handunnetthi L, Giovannoni G, Ebers GC, Ramagopalan SV Genetic and environmental factors and the distribution of multiple sclerosis in Europe. Eur J Neurol 2010, 17(9):1210-1214.

7. Tselis A: Epstein-Barr virus cause of multiple sclerosis. Curr Opin Rheumatol 2012, 24(4):424-428. 410.1097/BOR.1090b1013e3283542cf3283548.

8. Disanto G, Morahan J, Ramagopalan S: Multiple sclerosis: risk factors and their interactions. CNS Neurol Disord Drug Targets 2012, 11(5):545-555.

9. Simpson S Jr, Blizzard L, Otahal P, Van der Mei I, Taylor B: Latitude is significantly associated with the prevalence of multiple sclerosis: a meta-analysis. J Neurol Neurosurg Psychiatry 2011, 82(10):1132-1141.

10. Ascherio A, Munger KL: Environmental risk factors for multiple sclerosis. Part I: the role of infection. Ann Neurol 2007, 61(4):288-299.

11. Higgins J, Green S (Eds): Cochrane Handbook for Systematic Reviews of Interventions Version 5.0.2 [updated September 2009]; 2009.

12. Stroup DF, Berlin JA, Morton SC, Olkin I, Williamson GD, Rennie D, Moher D, Becker BJ, Sipe TA, Thacker SB: Meta-analysis of observational studies in epidemiology: a proposal for reporting. Meta-analysis Of Observational Studies in Epidemiology (MOOSE) group. JAMA 2000, 283(15):2008-2012.

13. The Newcastle-Ottawa Scale (NOS) for assessing the quality of nonrandomized studies in meta-analyses. [http://www.ohri.ca/programs/clinical_epidemiology/ oxford.htm]

14. Thacker EL, Mirzaei F, Ascherio A: Infectious mononucleosis and risk for multiple sclerosis: a meta-analysis. Ann Neurol 2006, 59(3):499-503.

15. Deeks JJ, Higgins JPT, Altman DG: Chapter 9: Analysing data and undertaking meta-analysis. In Cochrane Handbook for Systematic Reviews of Interventions Version 510 (updated March 2011). Edited by Higgins J, Green S, The Cochrane Collaboration; 2011.

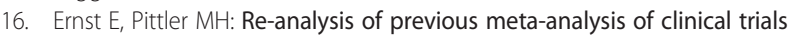
of homeopathy. J Clin Epidemiol 2000, 53(11):1188.

17. Peters $J$, Sutton AJ, Jones DR, Abrams KR, Rushton L: Comparison of two methods to detect publication bias in meta-analysis. JAMA 2006, 295(6):676-680.

18. Review Manager (RevMan) [Computer program]: 51st editionCopenhagen: The Nordic Cochrane Centre, The Cochrane Collaboration; 2011.

19. Schünemann HJ, Oxman AD, Vist GE, Higgins JPT, Deeks JJ, Glasziou P, Guyatt GH: Chapter 12: Interpreting results and drawing conclusions. In Cochrane Handbook for Systematic Reviews of Interventions Version 501. Edited by Higgins J, Green S, The Cochrane Collaboration; 2008.

20. Becker $H$, Chochon F, de Toffol B, Defebvre L, Leger JM, Pierrot-Deseilligny C, Sellal F: [Report of the 55th meeting of the American Academy of Neurology. Honolulu, March 29-April 6, 2003]. Rev Neurol (Paris) 2003, 159(4):470-486.

21. De Portugal AJ, Fereres JS: [Considerations on the relationship of injury and multiple sclerosis]. Med Clin (Barc) 1965, 44(4):252-255.

22. Goncharova ZA, Baliazin VA: [Risk factors of multiple sclerosis development in the population of the Rostov region]. Zh Nevrol Psikhiatr Im S S Korsakova 2009, 109(7 Suppl 2):10-15.

23. Kurtzke JF, Hyllested K: Multiple sclerosis in the Faroe Islands and the lack of protection by exposure in infancy. Neuroepidemiology 1992, 11(2):90-99.

24. Levine NS, Atkins A, McKeel DW Jr, Peck SD, Pruitt BA Jr: Spinal cord injury following electrical accidents: case reports. J Trauma 1975, 15(5):459-463.

25. Popescu D, Popescu VG: [Risk factors in multiple sclerosis: epidemiological studies in the Arges region]. Rev Med Interna Neurol Psihiatr Neurochir Dermatovenerol Neurol Psihiatr Neurochir 1981, 26(1):23-31.

26. Beziehungen W: Zwischen erkrankkungen ins Kindesalter und multiple-sklerose-erkrankung. Schweiz Arch Neurol Neurchir Psychiatr 1970, 106(2):311-317.

27. Delilović-Vranić J, Tiric-Campara M, Subasic N: Newly discovered MS cases. 12th Congress of the European Federation of Neurological Societies. 2008 Annual Meeting; 2008. August 23-26.

28. Beltran I, Molto-Jorda JM, Diaz-Marin C, Martin R, Matias-Guiu J: [Analytical epidemiological study of multiple sclerosis in Alcoi]. Rev Neurol 1998, 26(149):67-69.

29. Benedikz J, Magnusson H, Guthmundsson G: Multiple sclerosis in Iceland, with observations on the alleged epidemic in the Faroe Islands. Ann Neurol 1994, 36(Suppl 2):S175-179.

30. Boiko A, Deomina T, Favorova O, Gusev E, Sudomoina M, Turetskaya R: Epidemiology of multiple sclerosis in Russia and other countries of the former Soviet Union: investigations of environmental and genetic factors. Acta Neurol Scand Suppl 1995, 161:71-76.

31. Di Legge S, Piattella MC, Pozzilli C, Pantano P, Caramia F, Pestalozza IF, Paolillo A, Lenzi GL: Longitudinal evaluation of depression and anxiety in patients with clinically isolated syndrome at high risk of developing early multiple sclerosis. Mult Scler 2003, 9(3):302-306.

32. Frutos Alegria MT, Beltran-Blasco I, Quilez-lborra C, Molto-Jorda J, Diaz-Marin C, Matias-Guiu J: [The epidemiology of multiples sclerosis in Alcoi. Analytical data]. Rev Neurol 2002, 34(9):813-816.

33. Gusev El, Boiko AN, Demina TL, Sudomoina MA, Alekseev AP, Boldyreva MN, Trofimov D, Favorova OO: [The risk factors for the development of multiple sclerosis in the Moscow population. II. The combination of exogenous and hereditary factors]. Zh Nevrol Psikhiatr Im S S Korsakovo 1999, 99(6):47-52.

34. Gusev El, Boiko AN, Smirnova NF, Demina TL: [Risk factors of multiple sclerosis in Moscow population. I. Exogenous risk factors]. Zh Nevrol Psikhiatr Im S S Korsakova 1999, 99(5):32-40.

35. Gusev El, Zavalishin IA, Boiko AN, Khoroshilova NL, lakovlev AP: [Epidemiological characteristics of multiple sclerosis in Russia]. Zh Nevrol Psikhiatr Im S S Korsakova 2002, Suppl:3-6.

36. Kahana E, Zilber N, Abramson JH, Biton V, Leibowitz Y, Abramsky O: Multiple sclerosis: genetic versus environmental aetiology: epidemiology in Israel updated. J Neurol 1994, 241(5):341-346.

37. Karnaukh VN: [Epidemiology of multiple sclerosis in Amur region]. Zh Nevrol Psikhiatr Im S S Korsakova 2009, 109(8):59-62.

38. Li J, Johansen C, Bronnum-Hansen H, Stenager E, Koch-Henriksen N, Olsen J: The risk of multiple sclerosis in bereaved parents: a nationwide cohort study in Denmark. Neurology 2004, 62(5):726-729.

39. Meurman L, Wising P: [Multiple sclerosis, tonsillectomy, and herpes zoster varicellosus]. Lakartidningen 1966, 63(14):1318-1319.

40. Poser CM: The multiple sclerosis trait and the development of multiple sclerosis: genetic vulnerability and environmental effect. Clin Neurol Neurosurg 2006, 108(3):227-233

41. Souberbielle BE, Martin-Mondiere C, O'Brien ME, Carydakis C, Cesaro P, Degos JD: A case-control epidemiological study of MS in the Paris area with particular reference to past disease history and profession. Acta Neurol Scand 1990, 82(5):303-310.

42. Spitzer C, Bouchain M, Winkler LY, Wingenfeld K, Gold SM, Grabe HJ, Barnow S, Otte C, Heesen C: Childhood trauma in multiple sclerosis: a case-control study. Psychosom Med 2012, 74(3):312-318.

43. Warren $\mathrm{S}$, Cockerill R, Warren KG: Risk factors by onset age in multiple sclerosis. Neuroepidemiology 1991, 10(1):9-17.

44. Weilbach FX, Hartung HP: [Physical trauma and multiple sclerosis]. Nervenarzt 1997, 68(12):940-944.

45. Bangsi D, Ghadirian P, Ducic S, Morisset R, Ciccocioppo S, McMullen E, Krewski D: Dental amalgam and multiple sclerosis: a case-control study in Montreal, Canada. Int J Epidemiol 1998, 27(4):667-671.

46. Adams DK, Sutherland JM, Fletcher WB: Early clinical manifestations of disseminated sclerosis. BMJ 1950, 2(4676):431-436.

47. Hollander E: Trauma, multiple sclerosis, delayed sleep phase disorder, subjective experiences, and duration of illness in GAD. CNS Spectr 2008, 13(5):361-362

48. Horton AM Jr, Siegel E: Comparison of multiple sclerosis and head trauma patients: a neuropsychological pilot study. Int J Neurosci 1990, 53(2-4):213-215.

49. Mutlu N: Multiple sclerosis in Turkey; etiologic and symptomatologic study of four hundred ten cases. AMA Arch Neurol Psychiatry 1954, 71(4):511-516.

50. Selcen D, Anlar B, Renda Y: Multiple sclerosis in childhood: report of 16 cases. Eur Neurol 1996, 36(2):79-84.

51. Stazio A, Paddison RM, Kurland LT: Multiple sclerosis in New Orleans, Louisiana, and Winnipeg, Manitoba, Canada: follow-up of a previous survey in New Orleans, and comparison between the patient populations in the two communities. J Chronic Dis 1967, 20(5):311-332.

52. Kranz JM, Kurland LT, Schuman LM, Layton D: Multiple sclerosis in Olmsted and Mower counties, Minnesota. Neuroepidemiology 1983, 2(3-4):106-118.

53. Lauer K: Environmental associations with the risk of multiple sclerosis: the contribution of ecological studies. Acta Neurol Scand Supp/ 1995, $161: 77-88$. 
54. Lauer K, Firnhaber W: Prognostic criteria in an epidemiological group of patients with multiple sclerosis: an exploratory study. J Neurol 1992, 239(2):93-97.

55. Mellor A: Case-control study to collect medical and epidemiological data and blood samples for research into the causes of multiple sclerosis and selected demyelinating diseases. Waltham, MA: Accelerated Cure Project for MS; 2006:1-18.

56. Visscher BR, Clark VA, Detels R, Malmgren RM, Valdiviezo NL, Dudley JP: Two populations with multiple sclerosis. Clinical and demographic characteristics. J Neurol 1981, 225(4):237-249.

57. Alonso A, Hernan MA, Ascherio A: Allergy, family history of autoimmune diseases, and the risk of multiple sclerosis. Acta Neurol Scand 2008, 117(1):15-20.

58. Antonovsky A, Leibowitz U, Medalie JM, Smith HA, Halpern L, Alter M: Reappraisal of possible etiologic factors in multiple sclerosis. Am J Public Health Nations Health 1968, 58(5):836-848.

59. Brain $R$, Wilkinson $M$ : The association of cervical spondylosis and disseminated sclerosis. Brain 1957, 80(4):456-478.

60. Conradi S, Malzahn U, Schroter F, Paul F, Quill S, Spruth E, Harms L, Then Bergh F, Ditzenbach A, Georgi T, Heuschmann P, Rosche B: Environmental factors in early childhood are associated with multiple sclerosis: a case-control study. BMC Neurol 2011, 11:123.

61. The Coordinating Center and the Neurological Centers of the Cooperative Group: Cooperative Italian study on multiple sclerosis and risk factors: a case-control study. Ital J Neurol Sci 1987, Suppl 6:17-20

62. Alonso A, Cook SD, Maghzi AH, Divani AA: A case-control study of risk factors for multiple sclerosis in Iran. Mult Scler 2011, 17(5):550-555.

63. Alter M, Speer J: Clinical evaluation of possible etiologic factors in multiple sclerosis. Neurology 1968, 18(2):109-116.

64. Andersen $\mathrm{E}$, Isager $\mathrm{H}$, Hyllested $\mathrm{K}$ : Risk factors in multiple sclerosis: tuberculin reactivity, age at measles infection, tonsillectomy and appendectomy. Acta Neurol Scand 1981, 63(2):131-135

65. Antonovsky A, Leibowitz U, Smith HA, Medalie JM, Balogh M, Kats R, Halpern L, Alter M: Epidemiologic study of multiple sclerosis in Israel. An overall review of methods and findings. Arch Neurol 1965, 13:183-193.

66. Bansil S, Singhal BS, Ahuja GK, Riise T, Ladiwala U, Behari M, Cook SD: Multiple sclerosis in India: a case-control study of environmental exposures. Acta Neurol Scand 1997, 95(2):90-95.

67. Berr C, Puel J, Clanet M, Ruidavets JB, Mas $J$, Alperovitch A: Risk factors in multiple sclerosis: a population-based case-control study in Hautes-Pyrenees, France. Acta Neurol Scand 1989, 80(1):46-50.

68. Bobowick AR, Kurtzke JF, Brody JA, Hrubec Z, Gillespie M: Twin study of multiple sclerosis: an epidemiologic inquiry. Neurology 1978, 28(10):978-987.

69. Broadley SA, Deans J, Chataway SJ, Sawcer SJ, Compston DA: Multiple sclerosis and tonsillectomy: no evidence for an influence on the development of disease or clinical phenotype. Mult Scler 2000, 6(2):121-123.

70. Casetta I, Granieri E, Malagu S, Tola MR, Paolino E, Caniatti LM, Govoni V, Monetti VC, Fainardi E: Environmental risk factors and multiple sclerosis: a community-based, case-control study in the province of Ferrara, Italy. Neuroepidemiology 1994, 13(3):120-128.

71. Cendrowski W, Wender M, Dominik W, Flejsierowicz Z, Owsianowski M, Popiel M: Epidemiological study of multiple sclerosis in western Poland. Eur Neurol 1969, 2(2):90-108.

72. Currier RD, Eldridge R: Possible risk factors in multiple sclerosis as found in a national twin study. Arch Neurol 1982, 39(3):140-144.

73. Currier RD, Martin EA, Woosley PC: Prior events in multiple sclerosis. Neurology 1974, 24(8):748-754

74. da Silva KR, Alvarenga RM, Fernandez YFO, Alvarenga H, Thuler LC: Potential risk factors for multiple sclerosis in Rio de Janeiro: a case-control study. Arq Neuropsiquiatr 2009, 67(2A):229-234.

75. De Gennaro RE, Ragazzi M, Caniatti E, Cesnik P, Fazio V, Simioni V, Govoni I, Casetta E, Granieri E: Environmental risk factors in multiple sclerosis. Different exposure in 3 genetically distinct populations with analytical approach. Padova, Palazzo della Fiera: XL Congresso Società Italiana di Neurologia; 2009.

76. Dokuchaeva NN, Boiko AN: [Clinical and epidemiological study of multiple sclerosis in Volgograd city]. Zh Nevrol Psikhiatr Im S S Korsakova 2006, Spec No 3:4-10.
77. Dolan R: Epidemiological Review of the Cluster of Multiple Sclerosis within East Boston and Winthrop, MA: Possible Roles of Childhood Nutrition and Xenobiotics Exposure as Causative Factors for the Disease. http://www.areco.org/ms.pdf; 2003.

78. Gronning M, Riise T, Kvale G, Albrektsen G, Midgard R, Nyland H: Infections in childhood and adolescence in multiple sclerosis. A case-control study. Neuroepidemiology 1993, 12(2):61-69.

79. Gusev E, Boiko A, Lauer K, Riise T, Deomina T: Environmental risk factors in MS: a case-control study in Moscow. Acta Neurol Scand 1996, 94(6):386-394.

80. Hopkins RS, Indian RW, Pinnow E, Conomy J: Multiple sclerosis in Galion, Ohio: prevalence and results of a case-control study. Neuroepidemiology 1991, 10(4):192-199.

81. Koch MJ, Reed D, Stern R, Brody JA: Multiple sclerosis. A cluster in a small Northwestern United States community. JAMA 1974, 228(12):1555-1557.

82. Koch-Henriksen N: An epidemiological study of multiple sclerosis. Familial aggregation social determinants, and exogenic factors. Acta Neurol Scand Suppl 1989, 124:1-123.

83. Kurtzke JF, Hyllested K, Arbuckle JD, Bronnum-Hansen H, Wallin MT, Heltberg A, Jacobsen H, Olsen A, Eriksen LS: Multiple sclerosis in the Faroe Islands. Results of a case control questionnaire with multiple controls. Acta Neurol Scand 1997, 96(3):149-157.

84. Lamoureux G, Giard N, Jolicoeur R, Toughlian V, Desrosiers M: Immunological features in multiple sclerosis. BMJ 1976, 1(6003): 183-186.

85. Lauer K, Firnhaber W: Descriptive and analytical epidemiological data on multiple sclerosis from a long-term study in southern Hesse, Germany. In Multiple Sclerosis in Europe: An Epidemiological Update. edn. Edited by Firnhaber W, Lauer K. Darmstadt: LTV Press; 1994:147-158.

86. Martinez Sobrepera HJ, Cabrera Gomez JA, Tuero Iglesias A: [Exogenous factors in the aetiology of multiple sclerosis in Cuba. A study of cases and controls]. Rev Neurol 2001, 33(10):931-937.

87. Poskanzer DC: Tonsillectomy and multiple sclerosis. Lancet 1965, 2(7425):1264-1266.

88. Poskanzer DC, Sheridan JL, Prenney LB, Walker AM: Multiple sclerosis in the Orkney and Shetland Islands. II: the search for an exogenous aetiology. J Epidemio/ Comm Health 1980, 34(4):240-252.

89. Roshanisefat H, Bahmanyar S, Hillert J, Olsson T, Montgomery SM: Appendicectomy and multiple sclerosis risk. Eur J Neurol 2011, 18(4):667-669.

90. Westlund KB, Kurland LT: Studies on multiple sclerosis in Winnepeg, Manitoba, and New Orleans, Louisiana. I. Prevalence; comparison between the patient groups in Winnipeg and New Orleans. Am J Hyg 1953, 57(3):380-396.

91. YosefiPour G, Rasekhi A: Multiple sclerosis: a risk factor analysis in Iran. Arch Iran Med 2002, 5(3):191-193.

92. Zaadstra BM, Chorus AM, van Buuren S, Kalsbeek H, van Noort JM: Selective association of multiple sclerosis with infectious mononucleosis. Mult Scler 2008, 14(3):307-313.

93. Zilber N, Kahana E: Risk factors for multiple sclerosis: a casecontrol study in Israel. Acta Neurol Scand 1996, 94(6):395-403.

94. Zorzon M, Zivadinov R, Nasuelli D, Dolfini P, Bosco A, Bratina A, Tommasi MA, Locatelli L, Cazzato G: Risk factors of multiple sclerosis: a case-control study. Neurological Sciences 2003, 24(4):242-247.

95. Siva A, Radhakrishnan K, Kurland LT, O'Brien PC, Swanson JW, Rodriguez M: Trauma and multiple sclerosis: a population-based cohort study from Olmsted County, Minnesota. Neurology 1993, 43(10):1878-1882.

96. Sterne JAC, Egger M, Moher D: Chapter 10: Addressing reporting biases. In Cochrane Handbook for Systematic Reviews of Interventions Version 510 (updated March 2011). Edited by Higgins JPT, Green S. The Cochrane Collaboration; 2011.

97. Paffenbarger RS Jr: The effect of prior tonsillectomy on incidence and clinical type of acute poliomyelitis. Am J Hyg 1957, 66(2):131-150.

98. Paffenbarger RS Jr, Wilson VO: Previous tonsillectomy and current pregnancy as they affect risk of poliomyelitis attack. Ann N Y Acad Sci 1955, 61(4):856-868.

99. Siegel M, Greenberg M, Magee MC: Tonsillectomy and poliomyelitis. II. Frequency of bulbar paralysis, 1944-1949. J Pediatr 1951, 38(5):548-558.

100. Yamanaka N, Kataura A: Viral infections associated with recurrent tonsillitis. Acta Otolaryngol Suppl 1984, 416:30-37. 
101. Lucas RM, Hughes AM, Lay M-L, Ponsonby A-L, Dwyer DE, Taylor BV, Pender MP: Epstein-Barr virus and multiple sclerosis. J Neurol Neurosurg Psychiatry 2011, 82(10):1142-1148.

102. Bagos PG, Nikolopoulos G, loannidis A: Chlamydia pneumoniae infection and the risk of multiple sclerosis: a meta-analysis. Mult Scler 2006, 12(4):397-411.

103. Cook SD, Rohowsky-Kochan C, Bansil S, Dowling PC: Evidence for multiple sclerosis as an infectious disease. Acta Neurol Scand Supp/ 1995, 161:34-42.

104. Krone B, Oeffner F, Grange JM: Is the risk of multiple sclerosis related to the 'biography' of the immune system? J Neurol 2009, 256(7):1052-1060.

105. Jilek S, Schluep M, Meylan P, Vingerhoets F, Guignard L, Monney A, Kleeberg J, Le Goff G, Pantaleo G, Du Pasquier RA: Strong EBV-specific CD8+ T-cell response in patients with early multiple sclerosis. Brain 2008, 131(Pt 7):1712-1721.

106. Levin LI, Munger KL, Rubertone MV, Peck CA, Lennette ET, Spiegelman D, Ascherio A: Temporal relationship between elevation of epstein-barr virus antibody titers and initial onset of neurological symptoms in multiple sclerosis. JAMA 2005, 293(20):2496-2500.

107. Randal Bollinger R, Barbas AS, Bush EL, Lin SS, Parker W: Biofilms in the large bowel suggest an apparent function of the human vermiform appendix. J Theor Biol 2007, 249(4):826-831.

108. Franciotta D, Salvetti M, Lolli F, Serafini B, Aloisi F: B cells and multiple sclerosis. Lancet Neurol 2008, 7(9):852-858.

109. Correale J, Farez MF: The impact of environmental infections (parasites) on MS activity. Mult Scler 2011, 17(10):1162-1169.

110. Norgaard M, Nielsen RB, Jacobsen JB, Gradus JL, Stenager E, Koch-Henriksen $\mathrm{N}$, Lash TL, Sorensen HT: Use of penicillin and other antibiotics and risk of multiple sclerosis: a population-based case-control study. Am J Epidemiol 2011, 174(8):945-948.

111. Alder AC, Fomby TB, Woodward WA, Haley RW, Sarosi G, Livingston EH: Association of viral infection and appendicitis. Arch Surg 2010, 145(1):63-71.

112. Bernstein CN, Wajda A, Blanchard JF: The clustering of other chronic inflammatory diseases in inflammatory bowel disease: a population-based study. Gastroenterol 2005, 129(3):827-836.

113. Matsushita M, Takakuwa H, Matsubayashi Y, Nishio A, Ikehara S, Okazaki K: Appendix is a priming site in the development of ulcerative colitis. World J Gastroenterol 2005, 11(31):4869-4874.

114. Pender MP: CD8+ T-cell deficiency, Epstein-Barr virus infection, vitamin D deficiency, and steps to autoimmunity: a unifying hypothesis. Autoimmune Dis 2012, 2012:189096.

115. Laurin M, Everett ML, Parker W: The cecal appendix: one more immune component with a function disturbed by post-industrial culture. Anat Rec (Hoboken) 2011, 294(4):567-579.

116. Rosati G: The prevalence of multiple sclerosis in the world: an update. Neurol Sci 2001, 22(2):117-139.

117. Livingston EH, Fomby TB, Woodward WA, Haley RW: Epidemiological similarities between appendicitis and diverticulitis suggesting a common underlying pathogenesis. Arch Surg 2011, 146(3):308-314.

118. Fleming JO, Carrithers MD: Diagnosis and management of multiple sclerosis: a handful of patience. Neurol 2010, 74(11):876-877.

119. Krone B, Pohl D, Rostasy K, Kahler E, Brunner E, Oeffner F, Grange JM, Gartner J, Hanefeld F: Common infectious agents in multiple sclerosis: a case-control study in children. Mult Scler 2008, 14(1):136-139.

doi:10.1186/1471-2377-13-41

Cite this article as: Lunny et al:: Surgery and risk for multiple sclerosis: a systematic review and meta-analysis of case-control studies. BMC Neurology 2013 13:41.

\section{Submit your next manuscript to BioMed Central and take full advantage of:}

- Convenient online submission

- Thorough peer review

- No space constraints or color figure charges

- Immediate publication on acceptance

- Inclusion in PubMed, CAS, Scopus and Google Scholar

- Research which is freely available for redistribution

Submit your manuscript at www.biomedcentral.com/submit
C Biomed Central 